Henrik Emilsson

Continuity or change? The refugee crisis and the end of Swedish exceptionalism

MIM WORKING PAPER SERIES 18: 3

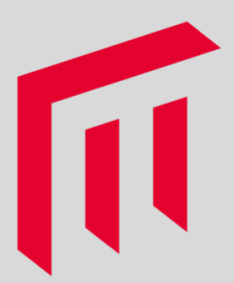




\section{MIM Working Papers Series No 18: 3}

\section{Published}

2018

\section{Editor}

Anders Hellström, anders.hellstrom@mah.se

\section{Published by}

Malmö Institute for Studies of Migration, Diversity and Welfare (MIM)

Malmö University

20506 Malmö

Sweden

Online publication

www.bit.mah.se/muep 
Henrik Emilsson

\title{
Continuity or change? The refugee crisis and the end of Swedish exceptionalism
}

\begin{abstract}
According to the policy-making literature, external shocks are one of the most important pre-requisites for major policy changes. This article investigates how the refugee crisis affected Swedish political parties' asylum and family migration policy preferences. The results indicate that the refugee crisis contributed to the breaking up of a long-established policy paradigm of openness and equal rights previously shared by most parties in parliament. A more fragmented party system has emerged where a new paradigm of controlling numbers has also found strong support outside the anti-immigration party the Sweden Democrats.
\end{abstract}

Key Words

refugee crisis; Sweden; policy change; migration policies; party politics

Bio Notes

Henrik Emilsson is a migration researcher at Malmö University. He defended his doctoral thesis 'Paper planes: Labour migration, integration policy and the state' in 2016. His current area of research are intra-EU youth mobility and migration- and integration policy.

\section{Contact}

Henrik.emilsson@mau.se 


\section{INTRODUCTION}

For a long time, Sweden has been an outlier with a relatively open migration policy and an integration policy based on equal rights (Emilsson, 2014). Compared to its neighbouring countries and most EU countries, Sweden has resisted the trend towards more restrictive migration policies and the introduction of civic integration policies (Goodman 2010, 2012). These policy choices have contributed to making Sweden one of the top choices for humanitarian migration. Since the early 2000s, no other OECD country has granted international protection to more persons per capita (UNHCR). When the Syrian and other conflicts escalated and pushed people to look for a safe haven in Europe, Sweden became the top choice for many of the asylum-seekers. The OECD (2016) concluded that, in 2014-2015, Sweden saw the largest per capita inflow of asylum-seekers ever recorded in an OECD country.

According to the policy-making literature, external shocks are one of the most important pre-requisites for major policy changes (Hajer, 2003; Sabatier and Weible, 2007). The mass influx of asylum-seekers did, indeed, cause panic in the political system, which resulted in several drastic, temporary, measures that went against long-standing traditions and migration policy principles in Sweden. The two most prominent measures were the introduction of external border controls and a new migration legislation adapted to EU minimum standards (Bill 2015/16:174). However, both measures are temporary. The border controls will eventually stop and the new migration law is designed as a three-year temporary solution. It is, thus, still unclear whether this is a temporary policy change similar to that in 1989-1991 (Johansson, 2005), or whether it is the start of a more longterm redirection of Swedish policies and a convergence to European mainstream migration policies.

This article uses the external shock of the refugee crisis to investigate migration policy position shifts among the political parties in Sweden. For now, the policy changes, according to the government, are a reaction to the immediate crisis. A longer-term policy change must find support among the political parties. Thus, the refugee crisis is a test of the resilience of the Swedish migration policy position - a position that, as I show, has until recently been defended by all political parties except the Sweden Democrats. The main question is whether or not the refugee crisis has affected migration policy positions among the political parties, and thus give an indication of whether or not Swedish exceptionalism is coming to an end. Although the investigation is empirical, the answer can shed light on the relevance of an external crisis as a factor in policy changes.

I study the political positions of the parties' migration policies before the crisis and compare them with their current policy positions, and how the political parties motivate their policies. Thus, I go beyond the focus on media and public 
debates that have previously received more attention in refugee crisis research (Triandafyllidou, 2017). For their policy positions before the crisis I use the latest party programs, released before the refugee crisis, together with manifestos from the 2014 election. The empirical material for party positions after the refugee crisis consists of two important migration policy debates in the Swedish parliament, the party motions related to those debates and the eventual new, official, party programs. The article concentrates on migration policy areas that are more directly connected to refugee situations: asylum and family migration, and the rights given to these categories after residence is granted.

The mapping of migration policies is two-dimensional. Researchers have noted that there seems to be a trade-off between migration policy openness and the rights which migrants are granted after admission (Ruhs, 2013). The trade-off between numbers and rights represents what Banting (2000) has called the two forms of welfare chauvinism: either a restrictive policy designed to deny resident foreigners access to social benefits under the same conditions as the citizen population, or a restrictive immigration policy designed to prevent foreigners from coming into the country and having access to comprehensive social programs. According to Banting, it is the second form of welfare chauvinism that is the most common in "expansive welfare states".

The remainder of the article begins with an overview of the theories on external shocks and policy change. After this, the major developments of the Swedish model for asylum and family-migration polices are analyzed in order to understand the context prevailing before the 2015 crisis. The next section describes the refugee crisis and how it affected Swedish society at large. The empirical section then looks at whether and how the political parties have reacted. Lastly, my empirical material is discussed in relation to the theoretical framework in a concluding discussion.

\section{EXTERNAL CHOCKS AND POLICY CHANGE}

Over the past decade or so, a number of scholars have stressed the role of ideas and knowledge in shaping policy-making, including in the field of migration (Balch, 2010; Bleich, 2002; Boswell et al., 2011). This kind of analysis moves beyond traditional political analysis on the electoral factors or the pluralist interplay of interest groups pioneered by Freeman $(1995,1998)$, which largely neglects the role of elites, institutions and ideas. Several competing and/or overlapping schools of thought with different concepts and emphases have developed. Policy frames (Entman, 1993) and policy paradigms (Hall, 1993) both discuss ideational frameworks that can be applied in any given policy field. Bleich (2002) defines a 
frame as a set of cognitive and moral maps that orient an actor within a policy sphere. Frames help actors to identify problems, interests and goals that point actors towards causal and normative judgements about appropriate policies in ways that propel the policy down a particular path. Policy frames suggest that ideas limit the possible policy choices, especially if they become taken for granted so that actors are unwilling or unable to think outside the box. Theoretical frameworks, such as Discourse Coalitions (Hajer, 2003) and Advocacy Coalitions (Sabatier \& Weible, 2007), operationalize the idea of frames. What the frameworks have in common is their belief in stable policy coalitions, and that the beliefs of policy participants are very stable over time, which make major policy changes very difficult.

According to the Advocacy Coalition Framework (ACF), belief systems are constituted of three layers. First, deep core beliefs span most policy subsystems and involve 'very general normative and ontological assumptions about human nature' (Sabatier \& Weible, 2007, p. 194). Deep core beliefs can be understood as the deeply entrenched ideology that structures the preferences of actors, such as the left/right divide and the relative priority given to fundamental values such as liberty and equality. Second, policy core beliefs are applications of deep core beliefs that span an entire policy subsystem. Because they are subsystem-wide in scope and deal with fundamental policy choices, they are also very difficult to change. Finally, secondary beliefs essentially address specific instruments or proposals dealing with only a subcomponent of a policy subsystem. Because secondary beliefs are narrower in scope than policy core beliefs, changing them is less difficult. The ACF predicts that it is unlikely that members of a coalition would voluntarily change core beliefs, as they are normative and very resistant to change in response to new information. Major exogenous shocks, such as changes in socio-economic conditions, regime changes, outputs from other policy subsystems or disasters are therefore seen as the only channel whereby major changes in policy core beliefs can take place.

Hajer (2003) has criticized the ACF for being too thin analytically to adequately account for the interactive dynamics of policy change. The ACF approach is, according to him, too general and neglects the social and historical context in which a policy change takes place. Instead, Hajer proposes the framework of discourse coalitions (DCF) which emphasizes narrative storylines rather than cognitive beliefs as the glue holding a policy coalition together.

While the professional "policy networks" relevant to the issue area might be interested in the validity of core cognitive factors, the broad majority of the members of a politically oriented policy coalition respond, according to Hajer (2003), to simplified storylines that symbolically reflect the concerns of core beliefs 
rather than the beliefs themselves. Consequently, it is not a belief system that constitutes the critical dynamic holding a policy coalition together but, rather, a persuasive narrative structure that provides orientation. As a way of thinking, it can also permit people with somewhat different core beliefs to continue to be part of the same coalition. A policy coalition can, for this reason, be much larger and more flexible than the advocacy coalition concept would indicate.

According to the DCF, policy change comes from discursive openings. Discursive openings are facilitated by the emergence of exogenous crises or shocks to the social system that make the tensions of dominant positions either visible or difficult to conceal. A crisis is thus a trigger for new forms of discursive responses that open or close off possible courses of action.

\section{THE DEVELOPMENT OF SWEDISH ASYLUM AND FAMILY MIGRATION POLICIES}

The 1976 Aliens Act (Bill 1975/76:18) laid the foundation for future Swedish asylum and migration policies which have been characterized as having an open asylum and family-migration policy and equal rights for foreigners. It introduced new protection grounds beyond what is required by the Geneva Convention and replaced temporary residence permits with permanent ones. According to the Minister for Migration, Anna Greta Leijon (S), this should be seen as a part of a general policy goal of granting foreigners the same rights and obligations as Swedish citizens (Parliament protocol 1975/76:44).

\section{Policy coalitions beyond the left-right political divide: 1976-1997}

The policy developments between 1976 and 1997 included both steps toward openness and a more closed asylum policy. Migration policies were often decided by a coalition of Social Democrats and the largest right-wing party, the Moderate Party. This latter occasionally pushed for a more-restrictive asylum policy and, on several occasions, the Social Democratic governments used a paragraph in the Aliens Act that made it possible to exclude non-Geneva Convention refugees from protection (Johansson, 2006). The most famous use of this power was the decision of 13 December 1989 in which the Social Democratic government, without consulting parliament, declared that the asylum reception system was in crisis and exempted three categories of asylum claim from the legislation. What was seen as especially pressing at the time was the arrival of around 6,000-8,000 TurkishBulgarian asylum-seekers.

By the end of the 1980s there was a growing polarization among the political parties. The new Aliens Act (Bill 1988/89:86) introduced two external 
policy measures - first safe country and carrier liability - making it harder for asylum-seekers to access the asylum process that was strongly opposed by the Liberal Party, the Green Party and the Left Party. This was the first time that a substantial element of the parliament fought for a more-generous asylum policy, and the three parties made an alliance with civil society organizations such as Save the children, Red Cross, the Church of Sweden and Amnesty (Öberg, 1994).

The 1990s could very well have ended with a much more restrictive asylum policy than that which was eventually voted in. Growing politicization, an antiimmigration party in parliament and a sharpening of bloc politics all contributed to the relative status quo. Firstly, the politicization came from the vocal opposition of political parties and civil society to the policy positions of the Moderates and the Social Democrats. Secondly, the 1991 elections saw a new anti-immigration party, New Democracy, entering parliament. Their presence not only contributed to the politicization of the asylum issue, but also made the Social Democrats and the Moderates less keen to push their policy through for fear of being associated with an anti-immigration party (Abiri, 2000). Thirdly, the 1991 elections opened the way for a centre-right government for the first time since 1982. As a concession to the Liberal Party, the Moderate Party adapted their migration policy in order to form a coalition government. For example, the new government did revoke the December 1989 decision, resetting the asylum law to its ordinary rules (Parliament protocol 1991/92:49).

\section{A period of expansive asylum policy: 1998-2014}

With few exceptions, the period starting from 1998 until the culmination of the refugee crisis in the autumn of 2015 meant a steady and gradual expansion of asylum policies. The asylum spikes of the early 2000s and from 2006 onwards did not lead to any political initiatives by the government to make asylum policies more restrictive. The Social Democratic government did put forward a proposal in the early 2000s to reduce asylum flows but found no support in parliament for their ideas (Bill 1999/2000:42). On the contrary, opposition parties pressured sitting governments towards openness. Compared to the 1970s, 1980s and 1990s, the tone of the debate gradually changed. The focus was no longer on migration control or integration considerations but, rather, on principles such as the rights of the child, equal rights in general, openness and the rule of law. For example, all parties endorsed the 2005 asylum bill (Bill 2004/05:170), which abolished direct political control over asylum decisions by creating migration courts. At the same time, the grounds for protection were extended. Children's own grounds for protection were given greater weight and a broader definition of protection 
grounds that included gender and sexual orientation was introduced.

Although the period overall meant a liberalization of asylum policy, the parliamentary debate was dominated by claims of inhumane asylum policies. The other parties accused the Social Democrats and the Moderates of constituting an "iron axle that maintains a restrictive policy" (Parliament protocol 2004/05:99, Anf. 26). This criticism coincided with the 2005 "Easter Uprising", the mobilization of civil society actors in favour of a general amnesty for rejected asylum-seekers. The two largest parties, the Social Democrats and the Moderate Party, rejected these demands. However, in the 2005 autumn budget, the Social Democratic minority government had to accept an amnesty to stay in power, which resulted in about 25,000 permanent residence permits being issued.

The later part of the decade, during the 2006-2010 centre-right government, was a calm period. The increase in asylum-seekers from Iraq in 2006 did not lead to any immediate reaction and the implementation of the EU qualification directive into Swedish law in 2010 (Bill 2009/10:31) happened without any substantial political debate, neither publicly nor in parliament. The implementation did not change earlier asylum policy, and all political parties supported the fact that Sweden chose to go beyond the EU minimum standards.

With the Sweden Democrats' success in the 2010 elections, an antiimmigration party was represented in parliament for the first time since 1991. Since the centre-right alliance now formed a minority government, it could have had major consequences for migration policy in general and asylum policy in particular. In order to de-politicize migration issues and isolate the Sweden Democrats, the alliance formed a framework agreement with the pro-migration Green Party to safeguard the right to asylum (Swedish Government, 2011). Most of the content in the agreement was implemented, including the bill to extend both the humanitarian protection grounds for children (Bill 2013/14:216), and rights for undocumented migrants (Bill 2012/13:58; Bill 2012/13:109).

\section{Family migration policies}

Compared to asylum policies, family migration policies have seen fewer political changes in recent decades. In 1997, a Social Democratic government implemented stricter eligibility criteria for family reunification (Bill 1996/97:25). After these restrictions, little happened despite several government commission investigations. A 2005 Commission report (SOU 2005:103, p 118f) discussed income requirements at some length and concluded that an income requirement would be very difficult to reconcile with both the principles of the universal welfare state and 
the general principles of fairness and equality. The subsequent government bill on family reunification (Bill 2005/06:72), which implemented the directive on family reunification into Swedish law, was accepted by all parties and went beyond the minimum EU standards. Sweden did not use the possibilities in the directive to give family members only temporary permits, or to require that migrants had housing, income and social insurance before they could be granted the right to reunification.

In 2010, the centre-right alliance government presented the first bill ever to introduce a support requirement for family migration in Sweden (Bill 2009/10:77). According to Borevi (2015), the motivation behind the 2010 reform deviates from policy debates in other European countries in that the support requirement is not presented as a way to prevent reunited families' access to public funds. Both the construction and the framing of the support requirement was adjusted so that it did not conflict with the ideology of the universal welfare state. The main argument for introducing the requirement was to encourage new arrivals to attain a position on the labour market, therefore those residing in Sweden for more than four years were exempt from it. Since refugees and persons with subsidiary protection were also exempt, very few people were eventually included in the target group. The Social Democrats, the Left Party, and the Green Party all voted against the bill and claimed that income requirements puts the Swedish welfare model at risk and would scare away potential asylum-seekers (Parliament protocol 2009/10:85).

At the start of the refugee crisis, Swedish family-migration policies were thus substantially more liberal than the majority of their counterparts across Europe due to the almost complete absence of requirements and to the equal rights status immediately acquired by admitted family members (Borevi, 2015).

\section{Sweden in comparative perspective}

Before the refugee crisis, Sweden had asylum and family-migration policies that went way beyond the EU minimum standards. Asylum was given to a larger groups than in other countries, and persons granted international protection immediately received permanent residence permits, equal socio-economic rights and the requirement-free possibility to reunite with their families. The Swedish openness to asylum and family migration has contributed to a migration profile that differs from most other European countries. Table 1 shows the immigration composition in Sweden between 2008 and 2013 compared to that of a selection of similar countries. For every year between 2008 and 2013, Sweden has had the largest share of refugees and family migrants among new immigrants - almost two out of three. 
This is a stark contrast to the neighbouring country, Denmark, with a yearly share around 15 per cent.

TABLE 1. Share of immigrants (permanent immigration by category of entry or of status change) who are given asylum or are family migrants, 2008-2013

\begin{tabular}{lllllll}
\hline & 2008 & 2009 & 2010 & 2011 & 2012 & 2013 \\
\hline Austria & & 32 & 34 & 32 & 21 & 19 \\
Belgium & 38 & 43 & 42 & 37 & 36 & 36 \\
Denmark. & 15 & 16 & 17 & 13 & 13 & 17 \\
Finland & 45 & 52 & 52 & 49 & 48 & 48 \\
France & 58 & 49 & 48 & 45 & 43 & 43 \\
Germany & 39 & 30 & 30 & 22 & 18 & 19 \\
Ireland & & 22 & 8 & 48 & 19 & 23 \\
Italy & 33 & 33 & 29 & 29 & 35 & 36 \\
Netherlands & 34 & 34 & 32 & 31 & 26 & 30 \\
Norway & 30 & 43 & 28 & 30 & 30 & 31 \\
Portugal & 40 & 33 & 35 & 39 & 38 & 36 \\
Spain & 20 & 25 & 19 & 17 & 15 & 20 \\
Sweden & 63 & 64 & 58 & 52 & 59 & 67 \\
United Kingdom & 15 & 16 & 13 & 15 & 16 & 16 \\
\hline
\end{tabular}

Source: OECD, 2010, 2011, 2012, 2013, 2014, 2015

The relatively liberal asylum and family-migration policies have been combined with a policy on equal rights. For example, Sweden has scored the highest in all the editions of the Migrant Integration Policy Index (MIPEX), which measures migrants' formal rights and the countries' adaptation to diversity. Another indicator of rights is the absence of civic integration policies in Sweden (Goodman, 2010).

\section{THE REFUGEE CRISIS}

According to official statistics from the Migration Agency, 162,877 persons applied for asylum in Sweden in 2015, comprising 12.4 per cent of all applications in the EU and more than six times greater than the EU per capita average (Eurostat, 2016). While, in the first half of the year, the number of applicants varied between 4,000 and 5,000 per month, in September it rose to 24,000 and, in October and 
November, reached almost 40,000. These record numbers were not solely due to Syrian asylum-seekers, who represented a little less than one third of applicants. More than a quarter were Afghani citizens, over half of whom were unaccompanied minors. In total, over 35,000 unaccompanied minors applied for asylum in Sweden in 2015-more than one third of the total number arriving in the European Union.

The first major political reaction to the refugee crisis was the October Agreement between the Social Democratic and Green Party government and the four centre-right parties (Swedish Government, 2015a). Only the Left Party, who did not accept the content, and the Sweden Democrats, who were not invited, were left out of the agreement. This agreement included 21 measures for a more orderly asylum reception, a more efficient settlement process and a dampening down of increased costs. Two of the measures - the extension of the target group for income requirements for family migration and the short-term introduction of temporary residence permits - were aimed at reducing the number of asylum-seekers.

The Social Democratic government, who did not want to wait for the long legislative process, decided on 12 November to introduce internal border controls (Swedish Government, 2015b). The result was the creation of a large temporary camp in the city of Malmö, where asylum-seekers had to wait for accommodation in other parts of the country - but this move did not significantly reduce flows to Sweden. On 24 November, more drastic measures were implemented when the government decided to introduce external border controls (Swedish Government, 2015c). Now, no one without an identity card was able to cross from Denmark to Sweden. Combined, these measures reduced the number of asylum applicants to about 3,000 per month during the first quarter of 2016.

The surge in numbers has affected capacity in a number of ways. First of all, the average processing time from application to decision in asylum cases went from as short as three months before the crisis to over 12 months in 2016 (Migration Agency, 2016). Second, the asylum reception system itself has come under severe strain. At the beginning of 2016, over 173,000 persons were enrolled in the system, which forces the Migration Agency to resort to both temporary and expensive solutions. There were also capacity problems for those granted protection and, by April 2016, about 13,000 persons still waited at reception centres for somewhere to live. Third, the housing situation was alarming, with overcrowding in socioeconomic and ethnically segregated neighborhoods (National Board of Housing, Building and Planning, 2015). Fourth, the numbers also put pressures on the introduction program for newly arrived immigrants organized by the Employment Service. When it was introduced in December 2010, the program was planned for about 16,500 participants (Bill 2009/10:60). The forecast has not held, and the number of participants reached 55,000 in February 2016. Estimates show that 
there will be close to 80,000 participants in 2017 , growing to over 100,000 in 2018-2020 (Employment Service, 2016). Due to the increase in participants, the Employment Service has identified a number of risk areas: overstretched personnel, increased administration, a lack of office space and of access to interpreters and translation services, measures and programs and the risk of a general lower quality in the introduction program. Fifth, the costs increased dramatically. The budget for migration and integration rose to almost 50 billion SEK in 2016, from a previous level of 10 billion SEK between 2006 and 2011 (Bill 2017/18:1).

The main political focus has been the adaptation of Sweden's migration policy, with the clear intention of reducing the number of asylum-seekers. The numbers put stress upon the asylum system and, according to the government, pose a serious threat to public order and internal security. Two strategies are used which are designed to limit access to the Swedish territory and reduce the attractiveness of Sweden as a choice for asylum-seekers. The border controls introduced on 24 November tried to close off access to the Swedish territory and thereby hinder persons applying for asylum. In addition, the government presented a proposal for a revised migration law with the intention of making Sweden a less attractive choice for asylum-seekers, a proposal which took effect on 20 July 2016 (Bill 2015/16:174).

The proposed migration law is limited to three years and adjusts most of the Swedish asylum and family-migration laws to the minimum level under EU law and international conventions. This means that, for the first time, Sweden is only granting temporary residence permits to all persons given asylum (with the exception of resettled refugees). A transition to a permanent residence permit is given if he or she can prove that they can support themselves once the temporary permit has expired. Family migration is also being restricted. Only persons with refugee status according to the Geneva Convention will have the right to family reunification, and the income requirement for family formation has been increased and extended to most groups. Altogether, the new migration law is a huge departure from the previous Swedish policy position. However, some migration and integration policies are still, in many respects, more liberal than in other comparable countries. There are still no civic integration requirements, such as language skills or civic tests, for permanent residence. In addition, all persons granted temporary residence permits are given the same rights to welfare as other residents.

\section{PARTY POSITIONS BEFORE AND AFTER THE CRISIS}

So far, the article has shown that Sweden has pursued a more open migration policy compared to most European countries and has combined this openness with the granting of equal rights to migrants after admission. The refugee crisis has 
challenged the principles of the migration policy, and the Swedish government has implemented external border controls and a more restrictive asylum and familymigration policy. However, the measures are only temporary and it is unclear how the migration and integration policies will develop in the future. In this section, I study the political parties and their policy positions both before and during/after the refugee crisis. The question is whether or not the parties have made changes to their policies and, if they have not yet done so, what kind of policy changes are proposed. In this analysis, I use the two-dimensional typology described in the introduction. Thus, I separate policy proposals on openness from policy proposals on rights given to migrants in Sweden.

\section{The Social Democratic Party}

Since 2014, the Social Democratic Party has been in a minority government together with the Green Party. Before coming to power in 2014, the party was in opposition during the eight-year centre-right government (2006-2014). During that time, the party was known to largely accept the policy position of the sitting government. Both their 2013 party program and 2014 election manifesto reflect the traditional Swedish policy positions of combining openness and equal rights for persons looking for asylum (Social Democratic Party, 2013, 2014). Three specific issues are represented in both party documents: the need for the EU to develop a common responsibility for asylum and migration issues, for persons in need of protection to find asylum in Sweden, and for all municipalities to take responsibility for the settlement of refugees. There were, thus, no signs of a repositioning on asylum policy before the 2015 refugee crisis.

As is shown in the section of migration policy developments in relation to the crisis, the government introduced temporary border controls and asylum and family-migration legislation, with the objective of reducing the immigration inflow. The Social Democratic Party was the clear driver of these policies, while the coalition party - the Green Party - only accepted because they wanted to stay in power. The government made one major change compared to the policy proposal sent out to stakeholders for comments. The minimum temporary residence permit was extended from 12 to 13 months. The stated reason was that a residence permit of more than one year provides the holder with the right to register in a municipality. In turn, registration with a municipality is the pre-requisite for equal rights to welfare provision. Thus, when it comes to a possible trade-off between numbers and rights, the Social Democrats clearly favor a reduction in numbers over a limitation of rights.

The political guidelines decided at the 2017 party congress (Social Democrats, 2017, p. 37) are not concrete but state that it is not possible for Sweden to apply an asylum legislation that is substantially different to that of other 
countries in the EU. They also emphasize the need for a functioning, common EU asylum system with more-harmonized legislation and implementation. Their website is more to the point and explains that the ability to offer a good reception to asylum-seekers and persons granted international protection has its limits and therefore "Sweden cannot accept an unlimited number".

The last major parliamentary debate on migration policies confirms these policy positions but does not say whether they want to make the temporary legislation permanent or not (Parliament protocol 2016/17:101, Anf.1). However, it is clear that both their framing of the policies and their policy positions have fundamentally changed compared to the period before the refugee crisis.

\section{The Centre-Right Alliance}

The Centre-Right Alliance ruled together between 2006 and 2014, the first four years as a majority government and the second term as a minority one. The Alliance comprised the Moderate Party, the Liberal Party, the Centre Party and the Christian Democrats, and entered the 2014 election with a common manifesto (Alliance, 2014), just as they did in 2006 and 2010.

The 2014 manifesto - We Build Sweden - signalled a very open migration policy. There were many suggestions for better integration policies involving administrative changes and the improvement of current policies, but there were no suggestions for major policy changes. Although, like the Social Democrats, they emphasize the need for the EU to take on a larger role, they clearly defend the position of being more generous than comparable countries.

\footnotetext{
Many people choose to come to our country. The Alliance government, together with the Green Party, has chosen a different path than that of many other European countries. Instead of closing the country off to the world, we have said that Sweden will pursue a humane asylum policy and be a haven for those fleeing persecution and oppression. We have shown that it is possible to put compassion in the first place and to open the door for those who need protection.
}

Looking at the individual Alliance parties' programs and election manifestos, the wider picture of openness and equal rights is confirmed. The Moderates' (2011) position on asylum mirrors that of the Alliance by emphasizing an increasing role and responsibility for the EU whilst, at the same time, safeguarding the right to asylum and confirms that Sweden should be more generous than other countries. However, in their 2013 action program (The Moderates, 2013) there is a new proposal for a slightly less open family-migration policy, which would mean an 
expanded target-group family-reunification income requirement as part of the work-life policy.

The Centre Party and Liberal Party share a vision of an even more open migration policy. In their ideological program, the Centre Party (2013) writes that they strive for open borders and free movement, as well as a generous and humane refugee and immigration policy. For a party that bases its values on people's equal rights and values there is, according to the program, no other logical position than to push for a world where people can move freely across borders. On the same note, the party program for the Liberal Party (2013) says that their vision is that freedom of movement be recognized as a human right worldwide. They suggest steps towards this goal at the EU level, with a liberalization of the visa policy and the abolition of the EU carrier responsibility. Within Swedish politics they strive for a more generous asylum policy, according to the program. Finally, the Christian Democrats' (2015) policy program is in line with the Alliance program, with an emphasis on a generous, common EU asylum and migration policy which takes into account people's need for protection and in which humanitarian considerations weigh heavily. The national policy focuses on safeguarding the rights of the child and keeping families together.

All four Alliance parties have substantially changed their position on asylum and family-migration policies but not to the same extent and not always in the same direction. The Moderates have made the biggest turnaround. They want to make the 2016 temporary law on migration policies permanent, with temporary residence permits and comprehensive requirements for family reunification (The Moderates, 2016). They also suggest several measures for Sweden's reception system for asylum-seekers and the undocumented, which would mean reduced rights for asylum-seekers -for example, fewer guaranteed hours of legal advice and a change in the law to guarantee that asylum-seekers and undocumented migrants have no access to social welfare. They also suggest new laws to expel more foreign criminals. At the 2017 Congress, the Moderates (2017) confirmed a permanent change of direction. A long-term sustainable and responsible migration policy, they write, means that temporary residence permits should be the main rule, and that income requirements should be the rule for all family migration. At the EU level, Sweden should push to replace the EU-wide asylum system with a new refugee quota system.

The Christian Democrats want to safeguard family reunification but agree with the now - among most parties - new consensus position that Sweden cannot have asylum and family-migration rules that depart significantly from those of other EU countries (The Christian Democrats, 2016). For the asylum policy, the party presents some suggestions in a variety of directions. They want to have moregenerous asylum rules for children with humanitarian needs. At the same time, they 
want to set up certain zones where all asylum-seekers must hand in their application and get a first assessment of their claims. They also want to make temporary residence permits a permanent feature in the Aliens Act. However, they want to make the permits of longer duration and to include rights for family reunification without any income requirements.

The Liberal Party (2016) acknowledges that the Swedish immigration laws need to be more in line with those of other European countries and are critical of current government policies. They are against all income requirements for family reunification in which children are involved and are also against the abolition of grounds for humanitarian protection. They are also critical of the shorter residence permits (13 months) for those with subsidiary protection and want to give everyone a three- year temporary residence permit.

It is not easy to pinpoint the policy position of the Centre Party. They acknowledge that, as long as immigration entails costs for the receiving country, there must be a balance in what a country can do (Parliament protocol 2016/17:101, Anf.21). However, the party still supports an open asylum and family-migration policy and, instead, concentrates on cutting costs for immigrants in the country. Among the four Alliance parties, the Centre Party is the most critical of temporary legislation and wants to have a more liberal family-migration policy and, in general, safeguard the right to protection (Parliament protocol 2016/17:41). The Centre Party is, thus, opening up to the reduction of some socio-economic rights for those granted asylum. Their policies are framed as aiming to "protects people's right to seek protection, but not all benefits" (Centre Party, 2016). However, the actual proposition to decrease migrant rights is not yet grounded in the party - for example in a party program.

\section{The Green Party, the Left Party, and the Sweden Democrats}

In their 2013 party program, the Green Party (2013) write that they are proud to be the most open party when it comes to migration policy. They criticize the common EU asylum policy for building walls against the surrounding world. They want everyone to be able to come to the EU and apply for asylum. Like the Liberal Party and the Centre Party, their vision is a world without borders, in which free movement is a human right. Nationally, they want to expand the grounds for humanitarian protection. Their election manifesto repeats the same priorities as the party program (Green Party, 2014) - they promise to always work for a more generous migration policy. Some more concrete promises are that family ties and health should weigh more heavily in asylum cases, that asylum for LGTB persons 
should be made more liberal and that persons who cannot be deported should get permanent residence permits after two years.

The Green Party is in the current 2014-2018 minority government together with the Social Democrats. In this way, they have presented and voted for the adaptation of Swedish asylum and family-migration policies to meet EU minimum standards. However, they still hold to the migration policy positions laid down in the 2013 party program or the 2014 election manifesto. Their goal is still that Sweden should take a large responsibility for refugees and be an international role model (Parliament protocol 2016/17:41, Anf. 118). In line with these goals, they want a return to the older legislation as quickly as possible (Parliament protocol 2016/17:101, Anf.12).

The party program for the Left Party (2012) is not very concrete but states that Sweden will pursue a humane refugee and asylum policy whereby every asylum-seeker is guaranteed the right to a humane and dignified individual assessment and with generous criteria for refugee status and asylum. The election manifesto (Left Party, 2014) repeats the same basic position and adds that legal channels to seek asylum must be established.

For a long time the Left Party has been advocating for a more open asylum and family-migration policy and they want to retract the June bill. They not only want to return to the previous legislation, but would like to open up for further liberalization in Sweden as well as in the EU (The Left Party, 2016). They want to tear down the walls around the EU and let the asylum-seekers decide for themselves the country in which they would like to apply for asylum. In order for the EU to be more accessible to asylum-seekers, the party wants to open up more legal ways - for example, by issuing humanitarian visas, abolishing the carrier responsibility, increasing resettlement and de-criminalizing non-profit smuggling. Lastly, they want to increase the eligibility for family reunification to children over 18 and to parents.

I do not need to allocate too much space to the Sweden Democrats, since they were the only political party that did not support Sweden's pre-crisis migration policy. Already before the crisis, the Sweden Democrats talked about keeping immigration to such levels that it does not pose a threat to national identity, 
prosperity and security (Sweden Democrats, 2011). The election manifesto (Sweden Democrats, 2014) contained suggestions that now are official policy - a reduction of the right to asylum and the introduction of temporary residence permits. They also suggest that migrants in general should have fewer socioeconomic rights during their first years in the country. Not surprisingly, the message from the Sweden Democrats is that they had been right all along and that other parties have finally understood the need for more restrictive policies (Parliament protocol 2016/17:101, Anf.3).

\section{CONCLUDING DISCUSSION}

Sweden has, for a long time, been the exception to the general trend in EU countries for more-restrictive migration policies and a reduction of rights for migrants (Emilsson, 2014). Thus, there has been no obvious trade-off between openness and rights in the Swedish case. This policy position has been supported by a dominant policy coalition that has exceeded left-right ideological differences, and the coalition thus resembles what Hajer (2003) describes as a 'discourse coalition'.

The refugee crisis has, indeed, functioned as an external shock and, today, most political parties are suggesting policies that would have been impossible before the refugee crisis. Neither the success of the anti-immigration party, the Sweden Democrats, in the 2010 election or the other forms of societal discontent with migration identified by Lucassen (2017), have significantly influenced the official policies of the established political parties, which entered the 2014 election with either a status quo position or advocating for a more-open asylum policy. Today, however, both the political debate in parliament and the official migration policy positions of most parties have changed drastically. Deeply entrenched principles and narratives among many of the seven 'old' parties have been discarded in favour of the overall goal of reducing the number of asylum-seekers and family migrants.

Where, earlier, there was one dominant coalition consisting of the majority of political parties, this coalition has fragmented into several elements. On the one hand we have the Moderates and the Social Democratic Party, together with the more-hesitant Liberal Party and the Christian Democrats, who guide their policies according to their overall goal of adapting policies to European standards in order to reduce asylum and family migration. The Green Party and the Left Party are still holding on to the traditional Swedish policies on migration, with a generous asylum policy, permanent residence permits and no income requirements for family migration. The odd one out is the Centre Party, which still advocates a generous migration policy while, at the same time, being open to reducing immigrants' socio- 
economic rights. In these changes, we have seen a break up of earlier policy coalitions (Hajer, 2003; Sabatier \& Weible, 2007) and we now have a more fragmented policy field that makes future policies more difficult to predict.

Thus, a new dominant policy paradigm acknowledging a need for a reduction in the number of asylum-seekers and family migrants, previously only consisting of the Sweden Democrats, have has emerged and is supported by a clear majority of the political parties. When it comes to rights, the majority of the parties still support the principle that legal residents should have equal rights independent of status and citizenship, thus confirming a long-standing tradition in Swedish migration policies that dates back to the late 1960s, when Sweden resisted the guest-worker system and introduced long-term residence permits for labour migrants.

\section{REFERENCES}

Abiri, E.

2000 "The changing praxis of "generosity": Swedish refugee policy during the 1990s", Journal of Refugee Studies, 13(1): 11-28.

Balch, A.

2010 Managing Labour Migration in Europe: Ideas, Knowledge and Policy Change, Manchester University Press, Manchester.

Banting, $\mathrm{K}$.

2000 "Looking in three directions: migration and the European welfare state in comparative perspective”, in M. Bommes \& A. Geddes (eds), Immigration and Welfare: Challenging the Borders of the Welfare State, Routledge, London: 13-33).

Bleich, E.

2002 "Integrating ideas into policy-making analysis frames and race policies in Britain and France", Comparative Political Studies, 35(9): 1054-1076.

Borevi, K.

2015 "Family migration policies and politics: Understanding the Swedish exception", Journal of Family Issues, 36(11): 1490-1508.

Boswell, C., A. Geddes, and P. Scholten

2011 "The role of narratives in migration policy-making: a research framework", The British Journal of Politics and International Relations, 13(1): 1-11.

Emilsson, $\mathrm{H}$.

2014 "Sweden", in A. Triandafyllidou \& R. Gropas (eds), European

Immigration: A Sourcebook, Ashgate, Farnham: 351-362.

Employment Service 
2016 Prognos för utbetalningar 2016-2020 [Expenditure prognosis 2016-2020] (AF2016/210014), Retrieved from http://www.arbetsformedlingen.se/download/18.209df489152dfb2317f49c $\mathrm{bb} / 1455869444365 /$ Prognos+f\%C3\%B6r+utbetalningar+20162020\%2C+201602.pdf.

Entman, R. M.

1993 "Framing: toward clarification of a fractured paradigm", Journal of Communication, 43(4): 51-58.

Eurostat

2016 Asylum in the EU Member States (44/2016), Retrieved from http://ec.europa.eu/eurostat/documents/2995521/7921609/3-16032017BP-EN.pdf/e5fa98bb-5d9d-4297-9168-d07c67d1c9e1.

Freeman, G. P.

1995 "Modes of immigration politics in liberal democratic states", International Migration Review, 29(4): 881-902.

1998 Toward a Theory of the Domestic Politics of International Migration in Western Nations, University of Notre Dame, South Bend.

Goodman, S. W.

2010 "Integration requirements for integration's sake? Identifying, categorising and comparing civic integration policies", Journal of Ethnic and Migration Studies, 36(5): 753-772.

2012 "Measurement and interpretation issues in civic integration studies: a rejoinder", Journal of Ethnic and Migration Studies, 38(1): 173-186.

Hajer, M.

2003 Discourse coalitions and the institutionalization of practice: the case of acid rain in Great Britain, in F. Fischer \& J. Forester (eds), The Argumentative Turn in Policy Analysis and Planning, Duke University Press, Durham, NC: 43-76).

Hall, P. A.

1993 "Policy paradigms, social learning, and the state: the case of economic policymaking in Britain" Comparative Politics, 25(3): 275-296.

Johansson, C.

2005 Välkomna till Sverige?: svenska migrationspolitiska diskurser under 1900talets andra hälft [Welcome to Sweden: Swedish Migration Policy Discourses During the Second Half of the 20th century], Bokbox Förlag, Malmö.

Lucassen, L.

2017 "Peeling an onion: the "refugee crisis" from a historical perspective", Ethnic and Racial Studies: 1-28 (Early View).

Migration Agency 
2016 Verksambets and utgiftsprognos April 2016 [Operation and Expenditure Forecast] (Dnr 1.1.3-2016-18258), Migration Board, Norrköping,

Retrieved from

http://www.migrationsverket.se/download/18.2d998ffc151ac3871598f92/ 1461750863230/Migrationsverkets+prognos+april+2016.pdf.

National Board of Housing, Building and Planning

2015 Boendesituationen för nyanlända [Housing Situation for the Newly

Arrived] (Rapport 2015:40), Retrieved from

http:/www.boverket.se/globalassets/publikationer/dokument/2015/boende situationen-for-nyanlanda.pdf.

OECD

2010, 2011, 2012, 2013, 2014, 2015 International Migration Outlook, OECD

Publishing, Paris.

2016 Working Together: Skills and Labour Market Integration of Immigrants and their Children in Sweden, OECD Publishing, Paris.

Ruhs, $\mathrm{M}$.

2013 The Price of Rights: Regulating International Labor Migration, Princeton University Press, New Jersey.

Sabatier, P. A. and C. M. Weible

2007 The advocacy coalition framework: innovations and clarifications, in P. A. Sabatier (ed.), Theories of the Policy Process, Westview Press, Boulder, CO: $189-217$.

Swedish Government

2011 Ramöverenskommelse mellan regeringen och Miljöpartiet de gröna om migrationspolitik [Framework Agreement Between the Government and the Green Party on Migration Policy], Retrieved from

http://www.regeringen.se/contentassets/f3ece2268a5a49f88722e4d66f9e8a aa/ramoverenskommelse-mellan-regeringen-och-miljopartiet-de-grona-ommigrationspolitik.

2015a Insatser med anledning av flyktingkrisen [Measures Due to the Refugee Crisis], Retrieved from http://www.regeringen.se/4aa54c/contentassets/6519e46a9780457f8f90e6 4 aefed1b04/overenskommelsen-insatser-med-anledning-avflyktingkrisen.pdf.

2015b Regeringen beslutar att tillfälligt àterinföra gränskontroll vid inre gräns [Government Decision to Temporarily Reinstate Internal Border Controls] [Press release], Retrieved from http://www.regeringen.se/artiklar/2015/11/regeringen-beslutar-atttillfalligt-aterinfora-granskontroll-vid-inre-grans/. 
2015c Regeringen föreslår åtgärder för att skapa andrum för svenskt flyktingmottagande [The Government Decides on Measures for Creating Breathing Space for Swedish Refugee Reception] [Press release], Retrieved from http://www.regeringen.se/artiklar/2015/11/regeringen-foreslaratgarder-for-att-skapa-andrum-for-svenskt-flyktingmottagandel.

Triandafyllidou, A.

2017 “A "refugee crisis" unfolding: "real” events and their interpretation in media and political debates", Journal of Immigrant and Refugee Studies: 1-19 (Early View).

Öberg, N.

1994 Gränslös rättvisa eller rättvisa inom gränser?, Almqvist and Wiksell, Stockholm.

Bills:

Bill 1975/76:18; Bill 1988/89:86; Bill 1996/97:25; Bill 1999/2000:42; Bill 2004/05:170; Bill 2005/06:72; Bill 2009/10:31; Bill 2009/10:60; Bill 2009/10:77; Bill 2012/13:58; Bill 2012/13:109; Bill 2013/14:216; Bill 2015/16:174; Bill 2017/18:1

Government Commissions:

SOU 2005:103

Parliamentary Protocols:

Parliament protocol 1975/76:44; Parliament protocol 1991/92:49; Parliament protocol 2004/05:99: Parliament protocol 2009/10:85; Parliament protocol 2016/17:41; Parliament protocol 2016/17:101

Party Documents:

The Alliance (2014) Vi bygger Sverige

The Centre Party (2013) En hållbar framtid: Våra idéer gör skillnad, Idéprogram

The Christian Democrats (2015) Principprogram

The Green Party (2013) Partiprogram

The Green Party (2014) Valmanifest 2014

The Left Party (2012) Partiprogram

The Left Party (2014) Vänsterpartiets valplattform för riksdagsvalet 2014

The Liberal Party (2013) Frihet i globaliseringens tid, partiprogram

The Moderate Party (2011) Ansvar för hela Sverige, Idéprogram

The Moderate Party (2013) Ett modernt arbetarparti för hela Sverige, Handlingsprogram

The Moderate Party (2017) En långsiktigt hållbar migrationspolitik. 
The Social Democratic Party (2013) Ett program för förändring

The Social Democrativ Party (2014) Kära framtid, Valmanifest för ett bättre Sverige. För alla.

The Social Democratic Party (2017) Security in a new era

The Sweden Democrats (2011) Principprogram, partiprogram

The Sweden Democrats (2014) Vi väljer välfärd, valmanifest

Party Motions:

The Centre Party 2016/17:3413; The Christian Democrats 2016/17:3302; The Liberal Party 2016/17:1065: The Moderate Party 2016/17:3371; The Left Party 2016/17:1200

Websites:

UNHCR, asylum statistics, available at http://popstats.unhcr.org/en/asylum_seekers

MIPEX, website at http://www.mipex.eu/ 